DOI: $10.11649 /$ abs.2018.002

\title{
Глеб Пилипенко
}

Институт славяноведения Российской академии наук

Москва

glebpilipenko@mail.ru

\section{Языковая ситуация межвоенного периода среди славянских меньшинств в Латгалии (по нарративам информантов)}

1. Латгалия отличалась этническим и конфессиональным многообразием среди всех регионов Латвии (Курляндия, Земгале, Видземе) на протяжении всего XX века, таковым регион остается и в XXI веке. Положение Латгалии на балто-славянском пограничье определило этническую специфику и историческую судьбу края. На историческое и культурное развитие Латгалии повлияло ее вхождение в середине XVI века в состав Речи Посполитой (Inflanty Polskie), после разделов которой эти земли отошли Российской империи (с 1802 г. входили в состав Витебской губернии). После распада империи Двинский, Люцинский и Режицкий уезды губернии вошли в состав Латвии. Дальнейшая судьба края складывалась в рамках Латвийского государства: до 1940 гг. существовала независимая Латвия, в 1940 г. Латвия включена в состав СССР, в 1941 оккупирована нацистской Германией, с 1944 г. существовала Латвийская ССР в составе СССР, после распада которого независимость Латвии была восстановлена. Многократная смена власти, вхождение в орбиту влияния разных идеологических и культурных центров, замешанное на весьма неоднородной этноконфессиональной основе, влекли за собой каждый раз и смену языковой 
политики, что приводило к формированию определенной языковой ситуации. Целью данной статьи является описание и характеристика языковой ситуации ${ }^{1}$ в регионе в межвоенный период, т.е. в период существования независимого Латвийского государства, по воспоминаниям представителей миноритарных славянских старожильческих сообществ, к которым прежде всего относят русских, поляков и белорусов ${ }^{2}$. В статье будут затронуты такие сферы языковой ситуации Латгалии в межвоенное время как усвоение латышского языка русскими, поляками и белорусами, а также ситуация со школьным образованием на языках национальных меньшинств; будет проведено сравнение с ситуацией послевоенного периода, а также проанализированы высказывания информантов по данной проблематике. Сами нарративы интересны тем, что в них используются различные дискурсивные практики (напр., включение цитаций, отсылки к чужой речи), а ход повествования развивается самостоятельно без вмешательства исследователя.

При характеристике языковой ситуации в первую очередь следует обратиться к переписям населения. Латгалия отличается от остальных регионов Латвии сложной этно-конфессиональной ситуацией. Перепись, проведенная в 1935 г., зафиксировала следующий конфессиональный состав в Латгалии: католики $57,51 \%$, православные $15,99 \%$, староверы $13,85 \%$, лютеране $7,47 \%$, иудеи $4,94 \%$ (Skrujenieks, 1938, c. 8). Что касается этнического состава, то латыши составляли $61,32 \%$, русские $27,15 \%$, евреи $4,93 \%$, поляки $3,45 \%$, белорусы $2,45 \%^{3}$. В послевоенный период национальный состав Латгалии претерпевает изменения: во-первых, Абренский край передается в состав Псковской области РСФСР, а во-вторых, в регион устремляются мигранты из других советских республик, прежде всего русскоговорящие. По данным всесоюзной переписи 1989 г. удельный вес русских в национальном составе Латгалии составлял 44\%, тогда как

1 Под языковой ситуацией мы понимаем «языковое обеспечение коммуникации в социуме» (Нещименко, 2003, с. 15).

2 Выделение группы славянских сообществ в качестве объекта исследования представляется нам оправданным, поскольку таким образом подчеркивается их особое положение внутри латвийского социума, этническая и лингвистическая близость, а также противопоставление по отношению к титульной нации. Говоря о славянских сообществах, мы не подразумеваем под этим понятием только русскоязычных, речь идет о тех, у кого первым языком в семейном общении является белорусский, польский или русский. К этой группе могут относится также те жители Латгалии, у которых родным языком является один из славянских, но которые официально записаны латышами. В Латгалии понятия этнической, религиозной и национальной принадлежности часто не совпадают.

3 В ходе проведения полевого исследования мы часто сталкивались со случаями неоднозначной идентификации информантов. Так, латышами обычно записывали католиков из польских и белорусских семей, при этом по-латышски/латгальски в их семьях могли и не говорить. Отмечено это и в других источниках: u vojennym bil'ec'e Pol'akf pašporc'e Łotyš (Ostrówka, 2015, c. 228). 
латышей - 41,6\%. На сегодняшний день пропорции изменились, так, согласно последней переписи 2011 г. латышей насчитывалось 46\%, русских 38,9\%, поляков $6,8 \%$, белорусов 4,9\%, однако русский язык в домашнем общении используют $54,6 \%$, латышский (в том числе латгальский) - 35,2\%. Современная ситуация отличается от той, которая складывалась в межвоенный период, когда доля использующих латышский язык в семье превышала половину (см. табл. 1). Представляют интерес данные, содержащиеся в переписи 1925 г. и свидетельствующие о том, в какой степени владели жители Латгалии государственным латышским и другими языками (см. табл. 2). Наименьший процент языковой компетенции в латышском языке зафиксирован у русских, далее следуют поляки и евреи. У латышей же отмечен самый большой удельный вес знания других языков (помимо латышского), за которым может скрываться владение русским языком. Из ситуации, когда только 7,05\% русских владели латышским языком и около половины латышей заявили о знании других языков (помимо латышского), можно сделать вывод, что в языковой ситуации наблюдался своеобразный перекос: языком национального меньшинства лучше владели представители титульной нации. Подобное состояние было унаследовано от Российской империи, после распада которой не прошло еще и десяти лет на момент проведения переписи. Русский язык оставался языком общения, в том числе, для поляков и евреев: так 70\% поляков и 65\% евреев ${ }^{4}$ указали владение другими языками (за исключением латышского), в этих цифрах можно уверенно предположить большой удельный вес русского языка 5 . После окончания Первой мировой войны латышский язык впервые становится государственным (Metuzāle-Kangere \& Ozolins, 2005, с. 318), расширяются сферы его применения: он вводится в программы учебных заведений в качестве изучаемого предмета, становится обязательным в армии. Прежние топонимы заменяются на латышские (Динабург/Двинск - Даугавпилс, Режица - Резекне и т.д.). С приходом к власти К. Ульманиса ${ }^{6}$ отмечается переход к латышизации образования; в частности, помимо сокращения количества школ для национальных меньшинств, вытесняется из сферы образования и латгальский язык (в 20-е гг. он преподавался в начальных классах и пережил определенный расцвет) (Lazdina \& Marten, 2012, с. 70). Следует отметить, что языковая ситуация в межвоенное время среди поляков подробно рассматривается в Jēkabsons (1996); о русском национальном меньшинстве пишут Волковс (Volkovs, 1996), Фейгмане (2000a,

${ }^{4}$ О языковом репертуаре евреев Латгалии находим свидетельство того, что торговцы и ремесленники могли изъясняться на латгальском, польском и русском языках (Senkāne, 2012, с. 836).

5 Особенно если принять во внимание, что 23\% поляков (5788), а также 4,4\% латышей (13445) использовали русский язык в домашнем общении.

${ }^{6}$ Карлис Ульманис (1877-1942) - премьер-министр, президент Латвии в межвоенное время. 
2000b, 2000c); белорусам в Латвии и языковой ситуации среди них посвящены работы Апине (Apine, 1995), Янковяка (Jankowiak, 2009). Современная языковая ситуации в Латгалии является объектом исследования в работе Шуплинской и Лаздиной (Šuplinska \& Lazdiņa, 2009).

\begin{tabular}{|l|l|l|}
\hline \multicolumn{1}{|c|}{ (Табл. 1) Языки, используемые дома } & \multicolumn{1}{c|}{1925 г. } & \multicolumn{1}{c|}{1930 г. } \\
\hline Латышский язык & $52,43 \%$ & $54,6 \%$ \\
\hline Русский язык & $34,09 \%$ & $31,58 \%$ \\
\hline Еврейский язык (идиш) & $5,55 \%$ & $5,11 \%$ \\
\hline Польский язык & $4,13 \%$ & $4,74 \%$ \\
\hline
\end{tabular}

\begin{tabular}{|c|l|l|l|l|}
\hline (Табл. 2) 1925 г. & \multicolumn{1}{|c|}{ латыши } & русские $^{8}$ & \multicolumn{1}{|c|}{ евреи } & \multicolumn{1}{|c|}{ поляки } \\
\hline Знает латышский и другие языки & $46,04 \%$ & $7,05 \%$ & $31,09 \%$ & $25,59 \%$ \\
\hline
\end{tabular}

Важным фактором, учитываемом при анализе языковой ситуации, является противопоставление городской и сельской среды ${ }^{9}$. Так, отмечается, что в самом Даугавпилсе в конце XIX века процент латышей был совсем небольшим, однако за пределами города латышское население было значительным (Volkov \& Kurczewski, 2013, c. 8).

2. Интересующий нас период является объектом изучения исторической социолингвистики, предполагающей также анализ статистических данных, архивных документов, газетных материалов того времени. Однако за сухими цифрами статистики зачастую остается человеческое измерение, судьба конкретного человека и восприятие им произошедших событий. Источником настоящего исследования послужили прямые и опосредованные воспоминания жителей Латгалии, нарративы информантов, представителей славянских сообществ края, записанные в ходе экспедиций в Латвию в 2016 и 2017 гг. ${ }^{10}$. Если

7 Все данные здесь и далее приведены по: см. раздел переписи.

8 В графу «krievi» (русские) включали также белорусов.

9 В Латгалии ранее более распространенным был хуторской тип поселения, который, вероятно, не способствовал интенсификации языковых контактов, как это имело место, напр., в городской среде.

10 Целью экспедиций был сбор социолингвистических и этнолингвистических сведений о старообрядцах Латгалии. За время проведения полевых исследований было опрошено 100 информантов из Даугавпилсского, Прейльского, Риебинского, Резекненского, Лудзенского, 
принять во внимание, что интересующая нас эпоха (20-30 гг. ХХ в.) отстоит от нас как минимум на восемьдесят лет, то становится очевидным, что непосредственных участников событий остается очень мало (те, кто родился во второй половине 20-х гг., в то время были детьми). Рассказы о том периоде становятся частью семейной истории, которая передается последующим поколениям, поэтому релевантной для нас была информация от детей, внуков и правнуков свидетелей тех событий ${ }^{11}$, ведь семья играет ключевую роль в конструировании нашей памяти (Ločmele, 2011, c. 92; Misztal, 2003, с. 19). М. Хальбвакс различает два вида памяти: внутреннюю (личную или автобиографическую) и внешнюю (социальную или историческую), которые взаимно переплетены, поскольку история нашей жизни одновременно является и частью всеобщей истории (Хальбвакс, 2005). В данном случае мы имеем дело одновременно с индивидуальной и коллективной памятью. Индивидуальной - поскольку каждый опыт неповторим и уникален, коллективной -поскольку в ряде нарративов можно выделить похожие ключевые сюжеты, стратегии поведения, сходство в построении повествования. Воспоминания людей, которые пережили общее событие, никогда не идентичны, поскольку в каждом человеке конкретное воспоминание вызывает различные ассоциации и чувства (Misztal, 2003, с. 11).

Особенностью нарративов и памяти о межвоенном времени является их четкая связь с локальной идентичностью рассматриваемых групп, ведь благодаря этому группы оказываются связаны между собой и противопоставлены соотечественникам - русским, полякам, белорусам - из окружающих стран (даже несмотря на более продолжительное по времени пребывание в составе одного государства, сначала в Российской империи, затем в составе СССР). Я. Ассман утверждает, что память является функцией вовлеченности личности в разнообразные социальные группы, начиная с семьи и кончая религиозной

Дагдского, Аглонского краев. Общее время записи интервью составило более 60 часов. В связи со смешанным характером населения региона, большим числом смешанных семей, а также с целью выявления типологических схождений в языке и культуре жителей Латгалии в орбиту исследования попали не только русские старообрядцы, но и православные, а также старожильческое население других национальностей - белорусы, поляки, латгальцы. Для анализа в настоящей статье из нашего корпуса текстов были отобраны нарративы, в которых речь шла о языковой ситуации межвоенного времени и в которых упоминался латышский язык, а также положение славянских языков в тот период. Поскольку таких высказываний было собрано много, так что их едва ли можно было бы представить в данной статье, приоритет для анализа был отдан тем нарративам, которые иллюстрировали конкретные истории в семьях информантов. Большинство опрошенных собеседников проживает в сельской местности, соответственно, их воспоминания также по большей части связаны с этой средой. Тем не менее несколько информантов являются жителями городов: Даугавпилса, Резекне, Лудзы.

11 Подобный подход к исторической социолингвистике опробован, в частности, в проекте о многоязычии в Дагестане. Основным источником информации о владении языками были свидетельства, восстановленные по воспоминаниям потомков (см. Добрушина, 2011, с. 63, 65). 
и национальной общностью (Ассман, 2004, с. 37). Коллективная память позволяет людям иметь определенную социальную идентификацию, как на индивидуальном, так и на общественном уровне. При этом реконструкция прошлого всегда зависит от современных идентичностей и контекстов (Misztal, 2003, c. 14). Именно индивидуальная и коллективная память информантов о межвоенном двадцатилетии обособляют изучаемые сообщества и служат объединяющим фактором, формируют идентичность говорящих. Кроме интервью, собранных в рамках полевых исследований в 2016 и 2017 гг., привлекались также другие источники: опубликованные тексты на русском, польском и белорусском языках, записанные на территории Латгалии (Jankowiak, 2009; Ostrówka, 2015); интервью о еврейской проблематике в Латгалии (Амосова, 2013).

В ходе разговоров с информантами преследовалась цель зафиксировать нарративы о языковой ситуации прошлого, конкретно - периода 20-30-х гг., а также выяснить актуальное языковое состояние. Само интервью было полуструктурированным, оно допускало определенную свободу собеседника в выборе тем и направлений беседы. Высказывания информантов, не спровоцированные специальными вопросами, а возникшие спонтанно, по воле собеседника, который в конкретный момент посчитал уместным сделать отступление, представляют особенную ценность. Именно нарративы являются важным лингвистическим средством проявления коллективной памяти об общем прошлом (Ilić, 2014, c. 243). С. Чмейркова пишет следующее о двух аспектах (субъективном и объективном) нарративных интервью: «... рассказ, письменный или же устный, дает нам информацию не только об объективном состоянии вещей, но и о субъективном восприятии вещей» (Чмейркова, 2006, с. 9).

В последнее время появились исследования, в которых анализируется коллективная память жителей Латгалии и затрагиваются вопросы идентичности. Объектом изучения становится послевоенный период (Ločmele, 2011; Takahashi, 2014), ситуация в приграничных районах в период между двумя войнами и после них (Lulle, 2016), а также отражение истории в музейных экспозициях (Gibson, 2015). Работа Ольги Цара (Cara, 2010) посвящена изучению идентичности русских женщин на латвийско-российском пограничье. Отдельно следует упомянуть исследование рецепции евреев и еврейской культуры в Латгалии (Амосова, 2013), где содержатся ценные сведения о языках, использовавшихся еврейской общиной в межвоенный период. Что касается анализа языковой ситуации в Латвии, то в большинстве работ рассматривается период послевоенного времени и современности (Hogan-Brun, Ozolins, Ramonienè, \& Rannut, 2008; Kḷave, 2011; Priedīte, 2005). 
3. При упоминании своих родственников по мужской линии собеседники отмечали, что те хорошо владели латышским языком, поскольку служили в то время в латвийской армии ${ }^{12}$. В межвоенный период существовала всеобщая воинская повинность, поэтому все мужчины проходили через армейский опыт (Lazdin,a, 2012, с. 278), вместе с которым приобретали и знание латышского языка. Приведем нарративы информантов ${ }^{13}$ :

[3.1.] Наверное в сорок восьмом каком-то [это было] | пришли по-латышски |отеи, латышский язык знал | он служил в армии |в латышское время | тада тожа [...] надо было обязательно тоже |ну говорит | за два месяца выучыл латышский язык |от $\mid$ сам он | грамоты было полтора класса (муж., рус., рус., ст., 1944, РК.) ${ }^{14}$.

[3.2.] Мой отеи | например| был пивовар и он всегда критиковал латышское пиво | но чтоб критиковать | его вначале надо попробовать | у него было очень много друзей латышей $\mid$ и в других соседних деревнях |он больше |ну и по-латышики говорить мог | потому что он служил в латвийской армии |в армии он учился латышскому языку | ну латгальский тот же знал| но в основном говорил по-русски (жен., рус., рус., ст., 1954, П.).

[3.3.] Но можа там эти |дальше курземцы и видземцы по-другому говорили |а это как-то | похожи |ну и наши | вот и мой отеи | он воевал |курляндский котел| вместе с латышами он пришел с войны по-латышски говорил|а так вот на толоке тоже один от другого учьлись | латыши от русских |русские от латышей | ну опшэм дружно жили (жен., рус., рус., ст., 1941, Р.).

Отметим, что все возникающие упоминания, связывающие службу в латвийской армии с языковой компетенцией в латышском языке, представляют собой отступление, а не основную тему повествования. Первое свидетельство интересно тем, что информант подчеркивает способность своего отца выучить латышский язык, при том что тот имел лишь самое начальное образование

12 Закон о государственном языке (опубликован в Valdības Vēstnesis Nr. 7, 1935. g. 9. janvāri), предусматривал обязательное использование латышского языка в армии, на флоте (п. 2), а также в государственных учреждениях (Likums par valsts valodu, n.d.).

13 В примерах отражаются только наиболее значимые фонетические особенности речи собеседников, напр.: яканье, дзеканье/цеканье, твердое произношение шипящих $\boldsymbol{u}, \boldsymbol{u}$, билабиальное $y$, смягчение согласных, твердое $р$. При помощи | обозначается короткая пауза, || указывает на более длительную паузу, [...] обозначает пропуск небольшого фрагмента. Примеры из других источников приведены в оригинальной орфографии.

14 После каждого высказывания информанта приводятся следующие данные: пол (мужской (муж.), женский (жен.)); национальность (русский (рус.), поляк (пол.), латыш (лат.)); родной язык (русский (рус.), польский (пол.), латышский (лат.)); конфессиональная принадлежность (старовер (ст.), католик (кат.)); год рождения; место записи интервью (Д. - Даугавпилс, Р. - Резекне., Л. Лудза, П. - Прейли, ДК. - Даугавпилсский край, РК. - Риебинский край, ЛК - Лудзенский край, ДаК - Дагдский край, ПК. - Прейльский край). 
(полтора класса). Последний нарратив хотя по времени выходит за рамки рассматриваемого периода ${ }^{15}$, все же позволяет сделать заключение, что до мобилизации отец собеседницы срочную службу проходил в латвийской армии еще в 30-е гг. В ее памяти образ отца и его знание латышского связан с армейским опытом и пребыванием среди латышей. Сам межвоенный период маркируется как латышское время (3.1.). Естественно, что такая возможность приобрести компетенцию в латышском языке была гендерно ограничена (в принципе знание языков было различно у мужчин и женщин, ср. статистику: среди русских 7135 мужчин и 4937 женщин указали, что знают латышский язык (Otrā tautas skaitī̌̌ana Latvijā 1925. gadā 10. februārī, 1925)). Показательно, что все свидетельства даны не непосредственными участниками тех событий, а их детьми, родившимися в 40-50-е гг., т.е. речь идет о передаче информации через одно поколение.

4. Латышский язык мог быть усвоен также в другой ситуации. По воспоминаниям наших информантов, практика ухода «в бурла́ки» способствовала приобретению компетенции в латышском языке. Так, среди жителей Латгалии слово «бурлак» приобрело значение - «человек, отправляющийся на заработки» (латыш. pelnnā gājējs) (Kḷavinska, 2012, с. 115). Речь идет о весьма распространенном явлении в Латгалии, возникшем в XIX в. и связанном с экономической отсталостью края. Латгальцы покидали родные места, чтобы отправиться на заработки, как правило - сезонные (ср. рус. пойти в бурла́ки, латыш. iet burlakos, латг. ìt burlakūs). Во времена Российской империи уезжали в основном в Санкт-Петербург, Центральную Россию, на Дальний Восток, а также в соседние прибалтийские губернии. С обретением Латвией независимости возможность поехать на работу в Россию утратилась, жители края чаще «уходили в бурлаки» в Ригу, Курляндию, наиболее развитые в экономическом отношении регионы страны (Kḷavinska, 2012, с. 116). В памяти информантов остались свидетельства об этом социально-экономическом явлении межвоенного периода:

[4.1.] А пры том | там же до войны много ездили в заработки туда-сюда $\mid$ ходзил хто (жен., рус., рус., ст., 1927, РК.).

[4.2.] А в бурла́ки ехали в Курземе | и сюда под Ригу ехали |к богатым | баронам | на заработки они там | делали дренаж| | | землю обустраивали [...] отеи у нас тоже ездил | на дренажные работы (жен., рус., рус., ст., 1942, ЛК.).

[4.3.] Xoził budavac' po Lifl'andiji xoz'it // jemu z'emí zupetńe ńe było (Ostrówka, 2015, c. 229).

На заработки отправлялись и мужчины, и женщины. Ниже приведем свидетельства того, что латышский язык использовался теми, кто уходил на

${ }^{15}$ Курляндский котел, осень 1944 - май 1945. 
заработки. У работников возникала необходимость в удачной коммуникации, которую можно было достичь, общаясь на языке, принятом в конкретной местности. Известно, что в Курляднии, в других латвийских регионах русский язык был менее распространен, чем в Латгалии (доля русских в населении Курляндии колебалась в межвоенный период в пределах одного процента).

[4.4.] Моя мать | например очэнь по-латышски говорила | она ездила молодой девушкой |в Курляндию| где это вот туда |Курляндия $\mid$ да| там были хозяева богатые | они лето работали там |им очэнь хорошо платили и они разговаривали по-латышски (жен., рус., рус., ст., 1947, РК.).

Таким образом, мы видим, как языковая компетенция в латышском языке ассоциируется с определенной социально-экономической практикой. Однако здесь не было строгих правил и каких-либо условий со стороны работодателей:

[4.5.] Папа е́жжал | и все е́жжали в Курляндию в бурла́ки |вот |сейчас | говорим латыши и русские! | вот в газеты пишется (показывает) яшшо ито |русского | чтоб это латысский язык а то штраф будет или [...] я не могу понять |я почаму ехали вот в бурла́ки и никто латысскый язык в йих ня спрашивал как уоот и папа рассказывал | садились вместе с хозяином за стол, тянула, горики, хозяйка с пе́чь |картошка $\mid$ ишы | ито было |ели (жен., рус., рус., ст., 1937, ДаК.).

Совершенно очевидно, что крупными помещиками, у которых работали выходцы из Латгалии, не обязательно могли быть латыши. При этом соприкосновение с миром за пределами своей общины имело определенные последствия для русских старообрядцев. Так, поход на работу, служба в армии предполагали общение с другими этническими и конфессиональными группами, что было связано с некоторыми ограничениями в быту после возвращения в общину:

[4.6.] Когда уже | брат пошел в армию | и пришел с армии | там уже он обшшался | или кто уехал |как говорили |в бурла́ки $\mid$ то | тогда уже не обшались [...] папа приязжал с этой $\mid$ с бурлак | уже с нашей посудой он с детям не ел| или мы дети не ели $\mid$ с этой посуды [...] после того пост отнясьти как говорили [...] общшались там $\mid$ может и с явреем $\mid$ может с латышами (жен., рус., рус., ст., 1927, РК.).

В других регионах Латвии «бурла́ки» приобретали знание латышского языка в процессе работы. Тем не менее, знание латышского могло не быть обязательным условием при найме на работу ${ }^{16}$. При этом период 20-30-х гг. характеризуется

16 Эта сфера деятельности отличалась от государственной службы, на которой, особенно в 30-е гг. от чиновников требовалось знание латышского языка: тогда это | не придавали большое значэние | вот уже когда на государственную службу поступал| то уж тут должно́ | знать латышскый язык $\mid$ ну $\mid$ если латышскый язык знаешь | то со стороны государства препятствий не было (муж., рус., рус., ст., 1926, Д.). Ср. также свидетельство информанта, связанное с латышизацией 
как «до войны» (4.1.), сама же практика называется «ездили в заработки» (4.1.), «в бурла́ки ехали» (4.2.), «е́жжали в бурла́ки» (4.4.). В отличие от службы в армии, данная социально-экономическая практика не была гендерно ограничена, женщины также уходили на сезонные работы.

5. Воспоминания и рассказы о школе также ассоциируются с приобретением компетенции на латышском языке в период межвоенного двадцатилетия. Если до распада Российской империи в области образования проводилась русификация, то после обретения независимости в школах вводится государственный язык ${ }^{17}$ (Šuplinska, 2012a, c. 397). Принятие Латвией закона об обязательном школьном образовании должно было способствовать уменьшению неграмотности. В 20-е гг. в Латгалии были организованы школы с русским, польским ${ }^{18}$ и белорусским языками обучения. Существовала разветвленная сеть еврейских школ. Делами школ национальных меньшинств занимались отделы при Министерстве образования (Фейгмане, 2000b). Однако в 30-е гг., особенно во второй половине 30-х гг., происходит постепенное сокращение школ с языками обучения национальных меньшинств. Период либерализации школьного образования сменился тенденцией к его латышизации ${ }^{19}$. В результате этого родители были вынуждены отдавать своих детей в латышские школы ${ }^{20}$. Отметим, однако, что полностью школы, гимназии с русским, белорусским, польским языками обучения ликвидированы не были. В крупных городах оставалась возможность посещать данные учебные заведения. Отличительной особенностью свидетельств о школьном образовании того периода является то, что здесь мы уже встречаемся с непосредственными участниками тех событий, с теми, кто в 30-е гг. были детьми и посещали школы.

школы: в 1934-ом году | когда Ульманис уволил с работь | вернее дал разрешение уволить с работы всех | кого считали нужным || ну а ему [деду] уже было слишком много лет| и он естественно не знал латышского языка (жен., рус., рус., ст., 1947, Д.).

17 Следует отметить, что и после обретения Латвией независимости в 1918 г. в латышских основных школах и гимназиях также изучали русский язык (Инфантьев, 1997).

18 В 1919 существовало 17 основных школ с польским языком обучения, в 1921 - уже 27 основных школ и 3 гимназии, в 1930 году количество школ увеличилось до 35 (LeśniewskaNapierała, 2016, с. 195).

19 Проводимая в 30-е гг. школьная реформа затронула и латгальцев. Если в предыдущий период обучение начиналось на латгальском языке, а латышский вводился с третьего класса, то после 1934 г. усилилась тенденция латышизации образования (Šuplinska, 2012a, c. 398).

20 Т. Фейгмане приводит данные, согласно которым в 1936/37 учебном году $42 \%$ русских обучалось в латышских школах (Фейгмане, 2000а). 
5.1. В памяти информантов, заставших ту эпоху, запечатлен не только период, когда они ходили в латышскую школу в 30-е гг., но и смена власти в Латвии в 40-х гг., что отражалось и на сфере образования.

[5.1.1.] Там была латышская школа|я латышскую школу кончил|за шесть лет пришлось выучить три гимна | три гимна! | начал «Dievs| svētī Latviju»| это латысский гимн || в сороковом году | «Вставай| проклятьем заклейменный!»| интернационал |русские пришли |гимн был|и пришли немиь | «Deutschland Deutschland über alles | ̈̈ber alles in der Welt» | три гимна за шесть лет |за шесть классов пришлось выучыть (муж., рус., рус., ст., 1927, Л.).

[5.1.2.] Я ходил так значыт | при Латвии ходил в латыцскую|когда оккупировали советы | ходил у русскую | при немиах я ходил тоже в русскую|ходил|вот потом | а потом |э|когда немцев прогнали | а опять в этой|в русской (муж., рус., рус., ст., 1926, Д.).

Так, в первом фрагменте информант представляет смену власти, цитируя названия гимнов, которые заучивали ученики. Исполнение гимна на определенном языке свидетельствует о проводимой языковой политике в конкретный период. Период независимой Латвии представлен гимном Карлиса Бауманиса «Dievs, svêtī Latviju». Второй информант рассказал, что он ходил в разные школы до 1940 г. и после.

5.2. Что касается собственно периода независимой Латвии, то в сознании собеседников отчетливо проявляется связь между посещением латышской школы и хорошей компетенцией в латышском языке. Собеседники, рожденные еще в самом конце 30-х гг., пошли в школу уже в другое время и по этому типу воспоминаний соотносятся с послевоенным поколением, посещавшим в основном русские школы.

[5.2.1.] А папа мой при Латвии | при Латвии папа мой закончил только два класса $\mid$ н нас [Скрудалиенская волость] близко не было никаких латышей $\mid$ только староверы кругом |один латыши жил там |за озером | папа с ним по-латышски говорил только так $\mid$ два класса закончивщи | но когда пошел в школу|с ним только по-латышски говорили |от он научился быстро (жен., рус., рус., ст., 1937, Д.).

[5.2.2.] У меня батя всё-всё говорил по- $\mid$ мы ходили в школу | я ничего не понимала | по-латышски | батя нам всё переводил| всё| папа | знал латышский язык [...] мама не | мама была неграмотная | батя нам всё| он кониил семь классов |как кончили вот сейчас десять классов кончают | он знал всё нам |задачи решал| по-латышски переводил |всё-всё по-латышски (жен., рус., рус., ст., 1936, Д.).

[5.2.3.] Правда |мои старшие тети |допустим|которые во времена Ульманиса в школу ходили | они латышский язык учили |поэтому у них с латышским языком немножко тегче [...] поэтому тетушки которые учились во время первой республики 
| вот ульманисовское время в латышских школах | те как бы знали когда-то его | да (муж., рус., рус., ст., 1957, Д.).

В этих примерах мы видим обращение к опыту старших, первым двум собеседницам по 80 лет, третьему информанту - 60 лет; все трое посещали в советское время русскую школу. Уже в (5.2.1.) обнаруживается закономерность, о которой речь была выше - связь между посещением латышской школы в межвоенное время и компетенцией в этом языке (с ним только по-латышски говорили |от он научился быстро). Местность, о которой идет речь, - современная Скрудалиенская волость Даугавпилсского края - не отличалась в то время высокой долей латышей ( у нас близко не было никаких латышей| только староверы кругом), таковой она является и в наши дни (8,7\% латышей по переписи 2011 г.), тем не менее языковую политику указанного времени характеризует тот факт, что русские (старообрядцы) посещали именно школу с латышским языком обучения. Похожее высказывание находим и в (5.2.3.). Знание латышского языка, приобретенное в то время, воспринимается положительно, что видно по воспоминаниям собеседницы (5.2.2.). Так, ее отец помогал детям по латышскому языку, переводил задания.

5.3. Показательно, что сами информанты, свидетели и участники описываемых событий, рассказывают о том, что латышскому языку тогда уделялось большое внимание, а ученикам предписывалось говорить по-латышски, причем не только во время уроков:

[5.3.1.] (А Вы латышский понимаете?) Ну-y|как я уже $\mid$ при Ульманисе $\mid$ три класса закончыла $\mid$ но $\mid$ русские были | а латышской язык был| так э-э|латышскый надо было |очэнь строгой учытель был $\mid$ так $\mid$ учыли | старались по-латыциски учыться (муж., рус., рус., ст., 1927, РК.)

[5.3.2.] Stroha zapraszczałosia razhawarywać, umiejesz ty, nie umiejesz, tol'ka na łatyszskim. Na urokach. A na pieramieny wyjszauszy, mieżdu saboj i to nie razrieszali hawaryć pa ruski tam ili pa pol'ski. Tol'ka pa łatyszski [JS 1923 Krasław, LV] (Jankowiak, 2009, c. 80).

По всей видимости, подобная практика была более распространена в период латышизации школы в 30-е гг. и из-за особенностей ее реализации запечатлелась в памяти информантов. Тема ужесточения школьной политики в плане использования латышского языка, закрытия школ национальных меньшинств или их перевода на латышский язык обучения, довольно часто возникает в интервью с собеседниками. Отправной точкой в сознании информантов является государственный переворот, осуществленный К. Ульманисом в 1934 г. (при Ульманисэ (5.3.3.); когда был переворот Ульманиса (5.3.4.), в тридиать четвертом (5.3.4- 
5.3.5.) $)^{21}$. Каждое воспоминание об этом событии снабжается иллюстрацией, семейной историей, которая передается последующим поколениям. Приведем примеры подобных рассказов:

[5.3.3.] А наша была русская || брат закончыл | чэтыре класса русских | пошел| это ж при Ульманисэ || пошел в татышскую | яго || он | был очэнь способный $\mid$ он был в чэтвертом | в чэтвертый посадили |а других в третий|сажали (жен., рус., рус., ст., 1927, РК.).

[5.3.4.] Учился по-польски |потом вот в тридиать четвертом |ну не знаю |может он два года походил в польскую | не помню || ивот когда был переворот Ульманиса | он сказал всё! | он ликвидировал национальные! | он| ну это национальное сознание чтоб у латыии- | латышский язык | игде было меньше этих поляков [закрыл школы] || а русских |все школы за- ну| такие тоже где там поменьше закрыли | закрыли | вот я знаю в Па́сине оставили ту польскую школу| ну может оставили одну где-то в каких-то центрах | гимназия тут тоже осталась | ну короче| позакрывали польские школы $\mid$ короче | польскую школу в Рунданах закрыли | была латышская (жен., пол., рус., кат., 1958, Л.).

[5.3.5.] В тридцать четвертом году $\mid$ да $\mid$ то во всех школах русский | белорусский| еврейские школь все были закрыты | и они все были переведены || а мать была в пятом классе | и вот она прибегает || домой такая веселая| а отеи сидит || читает | да | и вот мать прибегает | «Папа | папа | я остаюсь на второй год» || а он так говорит | «А кто тебе такое сказал что ты остаешься на второй год?» || «Ну как у нас сказали | что все учителя татыши | они ничего не понимают | на каком языке они говорят || все латыши | наших учителей нет |все| и мьь все на второй год» (жен., рус., рус., ст., 1951, Д.).

В (5.3.4.) речь идет о закрытии польской школы, а в (5.3.3. и 5.3.5.) - о переводе русской школы на латышский язык обучения. Фрагменты (5.3.3.) и (5.3.5.) показательны в том плане, что свидетельствуют о слабой эффективности такого подхода в первое время его реализации: в течение одного года ученики плохо усваивали материал, так что вынуждены были думать о том, чтобы остаться на второй год (в чэтвертый посадили | а других в третий|сажали (5.3.3.); наших учителей нет $\mid$ все $\mid$ и мы все на второй год (5.3.5.)). Во многие школы вместо

${ }^{21}$ Образ К. Ульманиса довольно часто предстает в рассказах информантов. Сказывается своего рода идеализация прошлого (Aarelaid-Tart \& Bennich-Björkman, 2012, с. 5). Ср.: Такого не было | не было $\mid$ а когда вот был Вульмин говорили | я яво ня помню| но я родивши при Вульмини | какой иарявал порядок || где было разбойство где было что где было чаво | нигде этого ничаво не было | вот так (жен., рус., рус., ст., 1937, ДаК.); Как на натуральном хозяйстве жили| как вот первый президент Ульманис как нашу деревню поднял|не было школы | он в каждой $\mid$ дьве | деревни | объединялись | одна начальная школа || и вот этого Ульманиса Карлиса | очэнь | дажэ-э| наши обожают | латгальцы (жен., рус., рус., ст., 1941, Р.); Все равно на своей земле| при Ульманисе своя же земля тоже была (муж., рус., рус., ст., 1945, ДК.). 
прежних учителей присылали новых - латышей ${ }^{22}$. Небольшую эффективность этой языковой политики подтверждают и другие свидетельства:

[5.3.6.] Uczitiel' hawaryt, a szto on tam hawaryt. Piszesz tam, hliadzisz, czytajesz, a szto heta znaczycca, nie znajesz [JS 1923 Krasław, LV] (Jankowiak, 2009, c. 80).

Тем не менее, спустя некоторое время учащиеся приобретали определенную компетенцию в латышском языке, что подтверждают нарративы (5.2.1.-5.2.3.). Скорее всего, в (5.3.4.-5.3.5.) описывается начальный этап данной практики, что, естественно, и запечатлелось в памяти информантов.

Перевод школ на латышский язык является также основной темой в (5.3.7.), где информант рассказывает историю своих родителей.

[5.3.7.] Собрали всех староверов |родителей в школу |да| собрали со всего округа которые ходили и предложили подумать на каком языке вы хотите чтоб ваших детей обучали | на русском или на латышском|эти мужики мудрые мудрецы | так сказать | совершили совет | совешэвали там | и решили так|русскый язык они знают | а государственный все равно надо учыть | без его нельзя | поэтому на латыциком |вот когда кончьлтся |это |восемь классов когда кончат | погда пусть сами выбирают на какой продолжать |русской| латышской (муж., рус., рус., ст., 1926, Д.).

В рассказе дается положительная оценка выбору родителей, приводится и обоснование данного прагматического выбора: необходимо было учить государственный язык, а сделать это можно было только в школе с латышским языком обучения. Говоря о закрытии школ национальных меньшинств, следует отметить еще и другой аспект: последствия для культурно-образовательной сферы национальных меньшинств в результате реализации подобной политики все же были негативные (ср. воспоминания о закрытии гимназии в Лудзе (Фейгмане, 2000с)).

5.4. В отдельную группу следует выделить нарративы-воспоминания, непосредственно иллюстрирующие языковую компетенцию в латышском языке учащихся. В них содержатся вставки - цитации на латышском языке (здесь можно говорить о переключении кода), которые характеризуют общую ситуацию. Они интересны именно своей конкретикой, теми картинами из детства, которые остаются в памяти и передают дух эпохи. Нарративы (5.4.1-5.4.2.) рассказаны участниками тех событий, (5.4.3.) является косвенной передачей воспоминания через поколение (от отца к дочери):

22 Так, в Латгалию было прислано 1500 учителей из других регионов Латвии (Šuplinska, 2012b, c. 731). 
[5.4.1.] Брат мой || был очэнь способный| и шесть классов латышской закончыл | а у нас были уроки | учытель всё громко | чытать | а ня так что себе под нос учьть уроки $|u|$ так || я запомнила что брат всё [читает] mēs klīstam mès klistam (смеется) | а что |ну какое слово по-русски я и ня знала (жен., рус., рус., ст., 1927, РК.).

[5.4.2.] В школе мы учыли | это не так | не так сложно ну| три года как сказать | мы уже говорили с- так|на бытовом уровне свободно говорили |ну бывало потеряешь карандаш |приходишь к учьтелю и так даже говоришь |Lüdzu skolotāj $|\boldsymbol{e}| \boldsymbol{s} \mid \boldsymbol{e s}$ pazudu savu krāslis ${ }^{23}$ karandašs (улыбка) || ну и вот они очэнь| эти|вот была учытельница эта |заведуюшшая || в основной школе чэтырехклассной|вот латышка | но она очэнь любила староверов (муж., рус., рус., ст., 1926, Д.).

[5.4.3.] Приехал поступать в гимназию $\|$ а он в Рунданах |как там учился?|каждый день после уроков $\mid$ и грит |как оставил его после уроков | то он выучился там какие-то предлоги аiz bez iekša по рёс (смех) | да| и он говорит |вот тут в Лузды сдать экзамены | и вытянул эты |предлоги эти |какие-то |ну это в русском же есть да? | предлоги есть о! | я сразу как с пушки! (смех) | и поступил в гимназию (жен., пол., рус., кат., 1958, Л.).

Собеседница вспоминает (5.4.1.), как ее брат, посещавший латышскую школу, готовился к занятиям дома. Ей самой, когда была маленьким ребенком, было непонятно значение латышских фраз, которые брат заучивал. Но эта картина и фраза mēs klīstam («мы бредем») осталась в ее памяти, как знак эпохи. Другой информант (5.4.2.) отмечает, что государственный язык можно было выучить за время обучения в латышской школе. Однако были и смешные моменты, которые естественно возникали в процессе овладения языком, тем более у детей. В качестве иллюстрации информант приводит фразу, представляющую собой переключение кода в данном нарративе - собственную цитату из детства: Lüdzu skolotāj $|e|$ я| es pazudu savu krāslis karandašs (Простите, учитель, э, я (рус.), я потерялся свой цветной карандаш (рус.)). Очевидно, что главный акцент фразы был на использовании русского слова в латышском высказывании - karandašs вместо ожидаемого zimmulis (а точнее - zimmuli в форме вин. п. ед.ч.). Здесь же мы видим и несколько отступлений от нормы грамматического характера: отсутствует окончание вин.п. ед.ч. (следовало бы ожидать karandaš-u), тогда как возвратное местоимение им оформлено (sav-u); вместо глагола pazaudèt (es pazaudejju) (по/терять) употреблен глагол pazust (прош.вр.: es pazudu) (пропасть, потеряться). После обращения к учителю происходит заминка, вначале используется личное местоимение первого лица из русского языка, затем вследствие самоконтроля оно исправлено на латышский аналог. Возможно, что это высказывание является сконструированным с целью дать представление о языковых трудностях. Что касается (5.4.3.), латышской

\footnotetext{
23 Так в оригинале.
} 
вставкой являются предлоги, которые отец собеседницы выучил и представил на экзамене при поступлении в латышскую гимназию. В данном случае речь не идет о цитации чужой речи, а просто о перечислении латышских предлогов: aiz, bez, iekša, no, pēc (за/от, без/кроме, внутри, от/с/из, после).

5.5. Последствием того, что представители национальных меньшинств посещали школу с латышским языком обучения, было также снижение компетенции в родном языке, о чем свидетельствует следующий нарратив:

[5.5.1.] Сватя говорила | ито брат у нее где-то служил и письма писал|якобы как на русском | а латышскими буквами | от | он не умел| не знал русского алфа́вита | от | учылся на латышском | и вопшэ староверы вот эти соседи вот эти были | они латышский знали |латгальский $\mid$ обычно |латгальский язык $\mid$ местный ${ }^{24}$ (жен., лат., лат./рус., кат., 1937, ДК.).

Поскольку русский язык отсутствовал в школе, письма из армии домой выходец из семьи русских староверов писал на русском, но латышскими буквами. Рассказанная история перекликается со свидетельством информанта из Латгалии, который в армии не мог писать по-русски и записывал русские слова еврейским алфавитом (Гехт, 2013, с. 284).

5.6. Помимо знания латышского языка, те, кто ходил в школы с польским или белорусским языком обучения, знакомились с литературной нормой этих языков (Jankowiak, 2009, с. 43). Представители польского и белорусского меньшинств воспринимают это время как возможность получить образование на польском и белорусском языке соответственно и как утраченную для них возможность (если они уже не могли посещать эти школы). За период с 1947 по 1949 гг. были закрыты польские школы (Leśniewska-Napierała, 2016, с. 197), с того времени образование в Латвии можно было получить только на латышском и русском (в отличие от 20-30-х гг.). После 1991 года были вновь открыты польские школы в Латгалии, тогда как белорусская школа функционирует на сегодняшний день только в Риге (Jankowiak, 2009, с. 83).

[5.6.1.] И тетя [...] тоже кончила польский гимназий|до войны [...] школь у нас не было 58 лет | после того как после войны была закрыта школа |и за это время не было польского языка | не было традиций (жен., пол., рус./пол., кат., 1947, Р.)

24 Показательно, что в местах компактного проживания славян с латгальцами могло происходить взаимное усвоение языков детьми: (А латышский язык вы выучили в школе?) Ну сребятами кругом |это тоже там это (муж., рус., рус., ст., 1927, Л.). Кроме того, есть свидетельства, что таким же образом мог быть усвоен идиш: Там было семей 100-150 было еврейс- и он когда [...] паианом был|через озеро |и там с этими еврейскими детьми играл || ну|конечно|уже и на еврейском говорил (жен., рус., рус., ст., 1951, Д.). См. подробнее (Гехт, 2013). 
[5.6.2.] Польская школа исторически закончила свое существование [в Даугавпилсе] в сороковом году | она вот здесь вот была|вернее так|сначала была польская гимназия |потом Ульманис когда пришел к власти в 34-ом году | там была реформа школ [...] у нас была белорусская гимназия когда-то |это было до войны еще (жен., рус., рус., ст., 1947, Д.).

[5.6.3.] A tak $w$ Piedrui, $w$ Wajwadach, w Pustyni [obecnie Robeżnieki] eta byli biełaruskije szkoły. [...] Tam byli dwa kampliekta. Pol'skij kampliekt dwa kłasa i biełaruskij kampliekt [...] Priedmiety byli [po białorusku]. Byli, biełaruskij kłas, tam zanimałsia adzin uczitiel [EC 1914 Krasław, LV] (Jankowiak, 2009, c. 80).

6. В послевоенное время языковая ситуация в Латгалии меняется, русский язык расширяет сферы своего функционирования. В школах с русским языком обучения преподается латышский язык, однако в небольшом объеме. Из соседних областей России и Белоруссии, из других республик СССР в Латгалию приезжают на работу мигранты, не владеющие латышским языком. Не было необходимости в изучении латышского языка, поскольку в определенных сельских районах, в городской среде, преобладало русскоязычное население. Информанты, все принадлежащие к старожильческим славянским сообществам Латгалии, так описывают новую языковую реальность (обозначаемую как советское время (6.2.) (6.4.)):

[6.1.] У нас же очень много этих же и белорусов тех же всё| им тут сразу сказали что будет этот государственный язык | естественно они не учили нукак|ну| а почему они будут учить? | а этот государств- латышский язык? | ну обще | если он приехал из Белоруссии | у нас там все русские|ну ведь все мы изучали русский язык! || а зачем ему учить? | нуесли так вот |я чисто |человечески|ну зачем?|ну если я хочу там |ну ладно! | учу | а не хочу и не учу |если мне это не нужно |и он не знали этого языка $\mid$ и они все уехали вот когда (жен., пол., рус., кат., 1958, Л.).

[6.2.] Да кто учился?! | в советское время | а надо был он? | в советское время | [...] татысский немецкий $\mid$ там $\mid$ какя $\mid$ штаны проти- |ну не брал в голови́|кто тут знал что все развалится в 90-х годах |никто ж не знал! (муж., рус., рус., ст., 1968, ПК.).

[6.3.] Отношение к латышскому языку|он был в школе |в расписании |были учебники | было всё| но отношение даже у учителей латышского языка к своему предмету || нуне было первостепенным (жен., рус., рус., ст., 1947, Д.).

[6.4.] В советское время этого не было $\mid$ у нас там | не знаю |один урок в неделю латыциского || дай бог (жен., пол., рус., кат., 1975, ДК.).

[6.5.] У нас такая | глубоко русские вот эти деревни кругом|вот вокруг |именно вот в этом месте | глубоко русские деревни | ито не было такого вот общения на латышском языке|не было (жен., рус., рус., ст., 1955, ПК).

В (6.1.) затрагивается проблема мигрантов, приехавших на работу в колхозы Лудзенского района Латвийской ССР (cp. Jankowiak, 2009, с. 64-66). Они не 
владели латышским языком, поскольку не чувствовали в этом необходимости, окружение было русскоязычным (ср. также в (6.5.)) Однако это обстоятельство оказалось решающим в дальнейшей их судьбе, после развала СССР они все уехали из Латвии. Тема смены политического режима в начале 90-х гг., как рубежа в очередном изменении языковой ситуации, возникает и в (6.2.), но уже в связи со школьным образованием: хотя в школе и изучался латышский язык, особого внимания и интереса у учеников он не вызывал. Этому находим подтверждение и в (6.3.), тогда как в (6.4.) мы видим, что количество часов латышского языка было недостаточным для его полноценного усвоения. Из приведенных нарративов следует, что необходимости в изучении латышского языка, а также среды, где можно и нужно было бы его применять, не было. Очевидно, что такая ситуация контрастирует с межвоенным периодом, а также с современной ситуацией. Информанты, выросшие именно в тот период, часто противопоставляют свое знание латышского языка языковой компетенции своих старших родственников, поскольку последние могли лучше говорить по-латышски из-за проводившейся в межвоенный период языковой политики.

7. Коллективная память представителей национальных меньшинств Латгалии напрямую и косвенно отражает языковую ситуацию в регионе в межвоенный период, начавшийся с обретением Латвией независимости и с утверждением латышского языка как официального. И если в темах нарративов можно обнаружить сходства (решения правительства затрагивали все население), то конкретные рассказы являются глубоко индивидуальными, передают ощущения человека, непосредственно затронутого проводимой языковой политикой. Эта индивидуальность проявляется через семейные предания, анекдоты, в любом случае в основе рассказа лежит небольшой сюжет, организованный вокруг конкретной темы, касающейся языковой ситуации в Латгалии. Информанты организуют повествование, привлекая разные дискурсивные практики (напр., цитации с переключением кода). Всего нами было рассмотрено несколько тематических групп воспоминаний информантов. Первая группа касается прохождения военной службы в латвийской армии, вторая группа затрагивает такую практику, как «походы в бурла́ки» и использование языков при трудовой деятельности, третья группа имеет отношение к школьному образованию. Очевидно, что весь комплекс рассмотренной проблематики и вся политика того времени были направлены на изучение латышского языка и его продвижение как государственного языка. Информанты, не являющиеся свидетелями того времени, связывают компетенцию своих старших родственников именно с реализацией конкретной языковой стратегии, и оценивают ее положительно. Как нам представляется, здесь проявляется прагматический подход: среднее поколение, от которого записано больше всего нарративов, ходило в школу уже 
после 1945 года и обычно владело латышским языком на низком уровне. Как следствие, они ощущают это как недостаток в современной языковой ситуации. Обращение к прошлому и упоминание источников усвоения латышского языка (армия, школа) является, с одной стороны, характеристикой эпохи, с другой в этом скрывается сожаление, что собственная языковая компетенция отстает от уровня владения языком, который был у их родителей, родственников. По этому показателю, ходившие в школу в 20-30 гг. сближаются с современным молодым поколением, получающим образование либо в латышских школах, либо в школах для национальных меньшинств по билингвальной программе и хорошо владеющим государственным языком (Hogan-Brun et al., 2008, с. 136-137). Что касается поляков, то для них важным является факт преемственности школы; не функционировавшие большую часть советского периода, они вновь проводят обучение на польском языке. Таким образом, у информантов складывается стереотипное восприятие того времени, напрямую связывающее между собой владение латышским языком и участие в определенных сферах общественной деятельности.

\section{Библиография}

Aarelaid-Tart, A., \& Bennich-Björkman, L. (2012). Baltic biographies at historical crossroads. Milton Park: Routledge. https://doi.org/10.4324/9780203805237

Apine, I. (1995). Baltkrievi Latvijā. Rīga: Latvijas Zinātṇu akadēmijas Filozofijas un sociolog̣ijas institūts.

Cara, O. (2010). Lives on the border: Language and culture in the lives of ethnic Russian women in Baltinava, Latvia. Nationalities Papers, 38(1), 123-142. https://doi.org/10.1080/00905990903394474

Gibson, C. (2015). Borderlands between history and memory: Latgalia in mnemohistory (IMESS master's thesis). Tartu.

Hogan-Brun G., Ozolins, U., Ramonienè, M., \& Rannut, M. (2008). In R. B. Kaplan \& R. B. Baldauf, Jr. (Eds.), Language politics and practice in the Baltic states, language planning and policy in Europe: Vol. 3. The Baltic states, Ireland and Italy (pp. 31-192). Clevedon: Multilingual Matters Ltd.

Iedzīvotāju kultūretniskie un migrācijas rādītāji, Latvijas 2011. gada tautas skaitī̌̌anas rezultāti [Results of the 2011 Population and Housing Census in Latvia]. (2016). (P. Veegis, Ed.). Rìga: Centrālā statistiskas pārvalde.

Ilić, M. (2014). Discourse and ethnic identity: The case of the Serbs from Hungary. Berlin: Otto Sagner Verlag. https://doi.org/10.3726/b11935

Jankowiak, M. (2009). Gwary białoruskie na Łotwie w rejonie krasławskim (studium socjolingwistyczne). Warszawa: SOW.

Jēkabsons, Ē. (1996). Poḷi Latvijā. Rīga: HESP. 
Kḷave, E. (2011). Language choice and usage in social interaction in Latvia: Discourse and practice. Etniškumo studijos / Ethnicity Studies, 2011(1-2), 42-79.

Kḷavinska, A. (2012). Burlaks/Бурлак. In I. Šuplinska (Ed.), Latgales lingvoteritoriālā vārdnīca [Лингвотерриториальньй словарь Латгалии] (Vol. 1, pp. 115-117). Rēzekne: Rēzeknes augstskola.

Lazdiña, S. (2012). Karaveirs/Солдат. In I. Šuplinska (Ed.), Latgales lingvoteritoriālā vārdnīca [Лингвотерриториальный словарь Латгалии] (Vol. 1, pp. 277-279). Rēzekne: Rēzeknes augstskola.

Lazdiņa, S., \& Marten, H. F. (2012). A continuous struggle for political recognition. Journal on Ethnopolitcs and Minority Issues in Europe, 11(1), 68-87.

Leśniewska-Napierała, K. (2016). Działalność organizacyjna mniejszości polskiej na Łotwie (dawne Inflanty Polskie). Studia z Geografii Politycznej i Historycznej, 5, 191-208. https:// doi.org/10.18778/2300-0562.05.09

Likums par valsts valodu. (n.d.). Retrieved August 11, 2017, from http://valoda.ailab.lv/latval/ vidusskolai/VALODA/v9-4.htm

Ločmele, K. (2011). (Ne)izstāstītā vesture: Skola. Mājas. Atminna. Rīga: LU SZF SPPI.

Lulle, A. (2016). Revitalising border: Memory, mobility and materiality in a Latvian-Russian border region. Culture Unbound, Journal of Current Cultural Research, 8, 43-61. https:// doi.org/10.3384/cu.2000.1525.168143

Metuzāle-Kangere, B., \& Ozolins, U. (2005). The language situation in Latvia 1850-2004. Journal of Baltic Studies, 36(3), 317-344. https://doi.org/10.1080/01629770500000121

Misztal, B. A. (2003). Theories of social remembering. Philadelphia, PA: Open University Press.

Ostrówka, M. (2015). Teksty ze wsi Darwinieki oraz z Iłukszty na Łotwie z komentarzem językowym. Acta Baltico-Slavica, 39, 219-237. https://doi.org/10.11649/abs.2015.021

Otrā tautas skaitī̌̌ana Latvijā 1925. gadā 10.februārī. (1925). (M. Skujenieks, Ed.). Rīga: Valsts statistiskā pārvalde. Retrieved August 11, 2017, from http://www.csb.gov.lv/sites/default/ files/1925_tautas_skaitisana.pdf

Priedìte, A. (2005). Surveying language attitudes and practices in Latvia. Journal of Multilingual and Multicultural Development, 26(5), 409-424. https://doi.org/10.1080/01434630508668413

Senkāne, O. (2012). Žydi/Евреи. In I. Šuplinska (Ed.), Latgales lingvoteritoriālā vārdnīca [Лингвотерриториальный словарь Латгалии] (Vol. 1, pp. 836-838). Rēzekne: Rēzeknes augstskola.

Skrujenieks, M. (1938). Latvijas statistikas atlass: Valsts statiskiskā pārvalde. Rīga.

Šuplinska, I. (2012a). Latgolys škola/Латгальская школа. In I. Šuplinska (Ed.), Latgales lingvoteritoriālā vārdnīca [Лингвотерриториальный словарь Латгалии] (Vol. 1, pp. 397-400). Rēzekne: Rēzeknes augstskola.

Šuplinska, I. (2012b). Školuotuojs/Учитель. In I. Šuplinska (Ed.), Latgales lingvoteritoriālā vārdnīca [Лингвотерриториальныцй словарь Латгалии] (Vol. 1, pp. 730-732). Rēzekne: Rēzeknes augstskola.

Šuplinska, I., \& Lazdiṇa, S. (Eds.). (2009). Valodas Austrumlatvijā: Pētījuma dati un rezultāti. Rēzekne: Rēzeknes Augstskola. 
Takahashi, S. (2014). Russian speakers in Latgale and "the socialist rituals" under socialism. In I. Saleniece (Ed.), Vēsture: Avoti un cilvēki: XXIII zinātniskie lasījumi: Vēsture XVII (pp. 443-448). Daugavpils: Daugavpils Universitātes Akadēmiskais apgāds "Saule”.

Trešà tautas skaitī̌̌ana Latvijā 1930. gadā. (1930). (M. Skujenieks, Ed.). Rīga: Valsts statistiskā pārvalde. Retrieved August 11, 2017, from http://www.csb.gov.lv/sites/default/files/1930_ tautas_skaitisana.pdf

Volkov, V., \& Kurczewski, J. (2013). The Latvians, Russians and Poles of present-day Daugavpils: Integration, acculturation and historical reconciliation. Riga: Zinātnē.

Volkovs, V. (1996). Krievi Latvijā. Rīga: Zinātnē.

Амосова, С. (Ed.). (2013). Утраченное соседство: Евреи в культурной памяти жителей Латгалии: Материалы экспедиций 2011-2012 годов. Москва: Сэфер.

Ассман, Я. (2004). Культурная память: Письмо, память о прошлом и политическая идентичность в высоких культурах древности (М. М. Сокольская, Trans.). Москва: Языки славянской культуры.

Гехт, М. (2013). Представления о еврейских языках. In C. Амосова (Ed.), Утраченное соседство: Евреи в культурной памяти жителей Латгалии: Материаль экспедииий 2011-2012 годов (рр. 272-284). Москва: Сэфер.

Добрушина, Н. (2011). Многоязычие в Дагестане конца XIX - начала XXI века: Попытка количественной оценки. Вопросы языкознания, 2011(4), 61-80.

Инфантьев, Б. (1997). Русский язык и литература в латышской школе 1920 - 1930-х годов. Даугава, 1997(5), 111-122. Retrieved August 11, 2017, from http://www.russkije. lv/ru/pub/read/infantjev_russkij_v_latishskoj_shkole_pub/

Нещименко, Г. П. (2003). Языковая ситуация в славянских странах. Москва: Наука.

Фейгмане, Т. Д. (2000a). Обязательное обучение. In Т. Д. Фейгмане, Русские в довоенной Латвии, 1920-1940 гг.: На пути к интеграции. Рига: БРИ. Retrieved August 11, 2017, from http://www.russkije.lv/ru/pub/read/russians-in-the-first-latvian-republic/feigmanechapt3-3.html

Фейгмане, Т. Д. (2000b). Правовые аспекты положения русской школы в Латвии. In Т. Д. Фейгмане, Русские в довоенной Латвии, 1920-1940 г2.: На пути к интеграции. Рига: БРИ. Retrieved August 11, 2017, from http://www.russkije.lv/ru/pub/read/russiansin-the-first-latvian-republic/feigmane-chapt3-2.html

Фейгмане, Т. Д. (2000c). Среднее образование: Русские гимназии. In Т. Д. Фейгмане, Русские в довоенной Латвии, 1920-1940 г2.: На пути к интеграции. Рига: БРИ. Retrieved August 11, 2017, from http://www.russkije.lv/ru/pub/read/russians-in-the-firstlatvian-republic/feigmane-chapt3-41.html

Хальбвакс, М. (2005). Коллективная и историческая память. Неприкосновенный запас, 2005(2-3), 8-27.

Чмейркова, С. (2006). Речь и конструирование идентичности носителей языка. In Г. П. Нещименко (Ed.), Актуальные этноязыковые и этнокультурные проблемы современности (Книга 1, pр. 82-98). Москва: Наука. 


\section{Bibliography (Transliteration)}

Aarelaid-Tart, A., \& Bennich-Björkman, L. (2012). Baltic biographies at historical crossroads. Milton Park: Routledge. https://doi.org/10.4324/9780203805237

Amosova, S. (Ed.). (2013). Utrachennoe sosedstvo: Evrei v kul'turnő̆ pamiati zhitelĕ Latgalii: Materialy èkspeditsiu 2011-2012 godov. Moskva: Sëfer.

Apine, I. (1995). Baltkrievi Latvijā. Rīga: Latvijas Zinātṇu akadēmijas Filozofijas un sociolog̣ijas institūts.

Assman, I. (2004). Kul'turnaia pamiat': Pis'mo, pamiat' o proshlom i politicheskaia identichnost'v vysokikh kul'turakh drevnosti (M. M. Sokol'skaia, Trans.). Moskva: Iazyki slavianskoŭ kul'tury.

Cara, O. (2010). Lives on the border: Language and culture in the lives of ethnic Russian women in Baltinava, Latvia. Nationalities Papers, 38(1), 123-142. https://doi.org/10.1080/ 00905990903394474

Chmeĭrkova, S. (2006). Rech' i konstruirovanie identichnosti nositeleŭ iazyka. In G. P. Neshchimenko (Ed.), Aktual'nye i ètnoiazykovye i ètnokul'turnye problemy sovremennosti (Kniga 1, pp. 82-98). Moskva: Nauka.

Dobrushina, N. (2011). Mnogoiazychie v Dagestane kontsa XIX - nachala XXI veka: Popytka kolichestvennol otsenki. Voprosy iazykoznaniia, 2011(4), 61-80.

Feŭgmane, T. D. (2000a). Obiazatel'noe obuchenie. In T. D. Feı̆gmane, Russkie v dovoennoŭ Latvii, 1920-1940 gg.: Na puti k integratsii. Riga: BRI. Retrieved August 11, 2017, from http://www. russkije.lv/ru/pub/read/russians-in-the-first-latvian-republic/feigmane-chapt3-3.html

Fĕgmane, T. D. (2000b). Pravovye aspekty polozheniia russkoŭ shkoly v Latvii. In T. D. Fer̆gmane, Russkie v dovoennoĭ Latvii, 1920-1940 gg.: Na puti k integratsii. Riga: BRI. Retrieved August 11, 2017, from http://www.russkije.lv/ru/pub/read/russians-in-the-first-latvian-republic/ feigmane-chapt3-2.html

Fer̆gmane, T. D. (2000c). Srednee obrazovanie: Russkie gimnazii. In T. D. Fer̆gmane, Russkie $v$ dovoenno ̌ Latvii, 1920-1940 gg.: Na puti k integratsii. Riga: BRI. Retrieved August 11, 2017, from http://www.russkije.lv/ru/pub/read/russians-in-the-first-latvian-republic/ feigmane-chapt3-41.html

Gekht, M. (2013). Predstavleniia o evreǐskikh iazykakh. In S. Amosova (Ed.), Utrachennoe

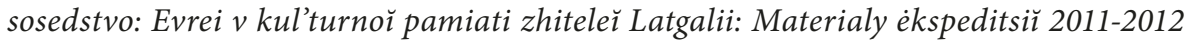
godov (pp. 272-284). Moskva: Sëfer.

Gibson, C. (2015). Borderlands between history and memory: Latgalia in mnemohistory (IMESS master's thesis). Tartu.

Hogan-Brun G., Ozolins, U., Ramonienė, M., \& Rannut, M. (2008). In R. B. Kaplan \& R. B. Baldauf, Jr. (Eds.), Language politics and practice in the Baltic states, language planning and policy in Europe: Vol. 3. The Baltic states, Ireland and Italy (pp. 31-192). Clevedon: Multilingual Matters Ltd.

Iedzīvotāju kultūretniskie un migrācijas rādītāji, Latvijas 2011. gada tautas skaitīšanas rezultāti [Results of the 2011 Population and Housing Census in Latvia]. (2016). (P. Végis, Ed.). Rìga: Centrālā statistiskas pārvalde. 
Ilić, M. (2014). Discourse and ethnic identity: The case of the Serbs from Hungary. Berlin: Otto Sagner Verlag. https://doi.org/10.3726/b11935

Infant'ev, B. (1997). Russkiŭ iazyk i literatura v latyshskoŭ shkole 1920 - 1930-kh godov. Daugava, 1997(5), 111-122. Retrieved August 11, 2017, from http://www.russkije.lv/ru/ pub/read/infantjev_russkij_v_latishskoj_shkole_pub/

Jankowiak, M. (2009). Gwary białoruskie na Łotwie w rejonie krasławskim (studium socjolingwistyczne). Warszawa: SOW.

Jēkabsons, È. (1996). Poḷi Latvijā. Rīga: HESP.

Khal'bvaks, M. (2005). Kollektivnaia i istoricheskaia pamiat'. Neprikosnovennyı zapas, 2005(2-3), 8-27.

Kḷave, E. (2011). Language choice and usage in social interaction in Latvia: Discourse and practice. Etniškumo studijos / Ethnicity Studies, 2011(1-2), 42-79.

Kḷavinska, A. (2012). Burlaks/Burlak. In I. Šuplinska (Ed.), Latgales lingvoteritoriālā vārdnīca [Lingvoterritorial'nyı̆ slovar' Latgalii] (Vol. 1, pp. 115-117). Rēzekne: Rēzeknes augstskola.

Lazdiṇa, S. (2012). Karaveirs/Soldat. In I. Šuplinska (Ed.), Latgales lingvoteritoriālā vārdnīca [Lingvoterritorial'nyı̆ slovar' Latgalii] (Vol. 1, pp. 277-279). Rēzekne: Rēzeknes augstskola.

Lazdiņa, S., \& Marten, H. F. (2012). A continuous struggle for political recognition. Journal on Ethnopolitcs and Minority Issues in Europe, 11(1), 68-87.

Leśniewska-Napierała, K. (2016). Działalność organizacyjna mniejszości polskiej na Łotwie (dawne Inflanty Polskie). Studia z Geografii Politycznej i Historycznej, 5, 191-208. https:// doi.org/10.18778/2300-0562.05.09

Likums par valsts valodu. (n.d.). Retrieved August 11, 2017, from http://valoda.ailab.lv/latval/ vidusskolai/VALODA/v9-4.htm

Ločmele, K. (2011). (Ne)izstāstītā vesture: Skola. Mājas. Atmiņa. Rīga: LU SZF SPPI.

Lulle, A. (2016). Revitalising border: Memory, mobility and materiality in a Latvian-Russian border region. Culture Unbound, Journal of Current Cultural Research, 8, 43-61. https:// doi.org/10.3384/cu.2000.1525.168143

Metuzāle-Kangere, B., \& Ozolins, U. (2005). The language situation in Latvia 1850-2004. Journal of Baltic Studies, 36(3), 317-344. https://doi.org/10.1080/01629770500000121

Misztal, B. A. (2003). Theories of social remembering. Philadelphia, PA: Open University Press.

Neshchimenko, G. P. (2003). IAzykovaia situatsiia v slavianskikh stranakh. Moskva: Nauka.

Ostrówka, M. (2015). Teksty ze wsi Darwinieki oraz z Iłukszty na Łotwie z komentarzem językowym. Acta Baltico-Slavica, 39, 219-237. https://doi.org/10.11649/abs.2015.021

Otrā tautas skaitī̌sana Latvijā 1925. gadā 10.februārī. (1925). (M. Skujenieks, Ed.). Rīga: Valsts statistiskā pārvalde. Retrieved August 11, 2017, from http://www.csb.gov.lv/sites/default/ files/1925_tautas_skaitisana.pdf

Priedìte, A. (2005). Surveying language attitudes and practices in Latvia. Journal of Multilingual and Multicultural Development, 26(5), 409-424. https://doi.org/10.1080/01434630508668413

Senkāne, O. (2012). Žydi/Evrei. In I. Šuplinska (Ed.), Latgales lingvoteritoriālā vārdnīca [Lingvoterritorial'nyı̆ slovar' Latgalii] (Vol. 1, pp. 836-838). Rēzekne: Rēzeknes augstskola. 
Skrujenieks, M. (1938). Latvijas statistikas atlass: Valsts statiskiskā pārvalde. Rīga.

Šuplinska, I. (2012a). Latgolys škola/Latgal'skaia shkola. In I. Šuplinska (Ed.), Latgales lingvoteritoriālā vārdnīca [Lingvoterritorial'ny̆̌ slovar' Latgalii] (Vol. 1, pp. 397-400). Rēzekne: Rēzeknes augstskola.

Šuplinska, I. (2012b). Školuotuojs/Uchitel'. In I. Šuplinska (Ed.), Latgales lingvoteritoriālā vārdnìca [Lingvoterritorial'nyı̆ slovar' Latgalii] (Vol. 1, pp. 730-732). Rēzekne: Rēzeknes augstskola.

Šuplinska, I., \& Lazdiņa, S. (Eds.). (2009). Valodas Austrumlatvijā: Pètījuma dati un rezultāti. Rēzekne: Rēzeknes Augstskola.

Takahashi, S. (2014). Russian speakers in Latgale and "the socialist rituals" under socialism. In I. Saleniece (Ed.), Vēsture: Avoti un cilvēki: XXIII zinātniskie lasījumi: Vēsture XVII (pp. 443-448). Daugavpils: Daugavpils Universitātes Akadēmiskais apgāds "Saule".

Trešā tautas skaitīšana Latvijā 1930. gadā. (1930). (M. Skujenieks, Ed.). Rīga: Valsts statistiskā pārvalde. Retrieved August 11, 2017, from http://www.csb.gov.lv/sites/default/files/1930_ tautas_skaitisana.pdf

Volkov, V., \& Kurczewski, J. (2013). The Latvians, Russians and Poles of present-day Daugavpils: Integration, acculturation and historical reconciliation. Riga: Zinātnē.

Volkovs, V. (1996). Krievi Latvijā. Rīga: Zinātnē.

\section{Языковая ситуация межвоенного периода среди славянских меньшинств в Латгалии (по нарративам информантов)}

\section{Резюме}

В статье рассматривается языковая ситуация в Латгалии в 20-30 гг. XX в. среди славянских меньшинств (русские, поляки, белорусы) через призму индивидуальной и коллективной памяти жителей края. В сознании информантов межвоенный период ассоциируется с господством латышского языка в официальных сферах коммуникации (армия, государственная служба, образование, официальная топонимика). Пребывание на службе, обучение в латышской школе, по свидетельствам информантов, способствовали развитию компетенции на латышском языке. Для поляков и белорусов 20-30 гг. были периодом, когда можно было получить образование на польском и белорусском языках. Рассмотренные случаи передают атмосферу времени, отражают коллективное восприятие эпохи; вместе с тем, каждый рассказ индивидуален, поскольку передает детали, характер восприятия, ощущения информантов (участников событий и их потомков). У информантов сложилось стереотипное 
восприятие того времени, напрямую связывающее владение латышским языком и участие в определенных сферах общественной деятельности.

Ключевые слова: языковая ситуация; Латгалия; латышский язык; русский язык; другие славянские языки; образование; память; межвоенный период

\title{
The language situation of the Slavic minorities in Latgale in the interwar period (according to the narratives of the informants)
}

\begin{abstract}
This article presents the language situation of the Slavic minorities (Russians, Poles and Belarusians) in Latgale in the 1920s and 1930s in individual and collective memory. As perceived by the informants, the interwar period is associated with the dominance of the Latvian language in the public sphere (the army, public service, education, official place names). In their view, military service and education at Latvian schools contributed to the development of Latvian language competence among national minorities. On the other hand, the 1920s and 1930s were also a period when Poles and Belarusians had access to education with their native language as the language of instruction. Although the accounts under consideration reflect a collective perception of the period and reveal its atmosphere, each of them is unique as it includes particular details and conveys feelings of individual informants (participants in the events and their descendants). The informants developed a stereotypical perception of the period, according to which there was a direct link between the level of command of the Latvian language and participation in certain spheres of public activity.
\end{abstract}

Keywords: language situation; Latgale; Latvian language; Russian language; Slavic languages; education; memory; interwar period 


\section{Sytuacja językowa mniejszości słowiańskich w Latgalii w okresie międzywojennym \\ (w narracjach respondentów)}

\section{Streszczenie}

Artykuł przedstawia sytuację językową mniejszości słowiańskich (Rosjan, Polaków i Białorusinów) w Łatgalii w okresie międzywojennym w pamięci indywidualnej i zbiorowej. W odczuciu respondentów lata 20. i 30. XX wieku były okresem dominacji języka łotewskiego w sferze publicznej (wojsku, administracji, oświacie, oficjalnym nazewnictwie). Ich zdaniem, służba wojskowa i nauka w łotewskich szkołach przyczyniały się do wzrostu stopnia znajomości języka łotewskiego wśród mniejszości narodowych. Z drugiej zaś strony, w tym samym okresie Polacy i Białorusini mieli dostęp do edukacji w języku ojczystym. Pomimo tego, że omawiane narracje oddają zbiorowe opinie na temat lat międzywojennych i ich atmosferę, każda $z$ nich jest jedyna w swoim rodzaju, zawiera bowiem konkretne szczegóły przywoływane przez respondentów (uczestników wydarzeń lub ich potomków) i ich osobiste odczucia. Badane osoby wyrobiły sobie stereotypowy obraz omawianego okresu, zgodnie z którym zachodził bezpośredni związek pomiędzy stopniem znajomości języka łotewskiego a uczestnictwem w określonych sferach życia publicznego.

Słowa kluczowe: sytuacja językowa; Łatgalia; język łotewski; język rosyjski; języki słowiańskie; okres międzywojenny

Dr Gleb Pilipenko works at the Institute of Slavic Studies of the Russian Academy of Sciences in Moscow, where he received his PhD in Philology in 2011. His scholarly interests include contact linguistics, Slavic dialectology and ethnolinguistics. He investigates the language and identity of Slavic minority groups and the language situation of Hungarians living among Slavic peoples. Gleb Pilipenko has also conducted field studies in Europe and South America.

Bibliography (selected): Языковая и этнокультурная ситуация воеводинских венгров: взгляд «изнутри» и «извне» [The language and ethno-cultural situation of Hungarians in Vojvodina: A view "from inside" and "from outside"], Москва (Moscow), Санкт-Петербург (Saint Petersburg) 2017; The Ukrainian language in Argentina and Paraguay as an identity marker, Slověne. International Journal of Slavic Studies, vol. 7, no. 1, Moscow 2018, 281-307; Hungarian-Slavic bilingualism in Transcarpathia, Vojvodina and Prekmurje, Yearbook of Finno-Ugric Studies, vol. 
10, no. 1, Izhevsk 2016, 20-30; Метаязыковые высказывания старообрядцев Латгалии [The metalinguistic utterances of Old Believers in Latgale], Славянский альманах 3-4, Москва (Moscow) 2017, 380-407; Переключение кода в русском языке старообрядцев Латгалии [Code-switching in Russian by Old Believers in Latgale], Jezikoslovni zapiski 1, Ljubljana 2017, 153-171.

Correspondence: Gleb Pilipenko, Institute of Slavic Studies, Russian Academy of Sciences, Moscow, e-mail: glebpilipenko@mail.ru

Support of the work: This work was supported by the Russian Science Foundation, grant no. 16-18-02080 "Russian language as the basis of preservation of cultural identity of Old Believers in Central and South-Eastern Europe".

Competing interests: No competing interests have been declared. 